\title{
ラットスポンジ移植モデルに括ける遺伝子組換え型 ヒ卜塩基性線維芽細胞成長因子の創傷治瘾促進
}

\author{
山岡万寿夫・正木恒男・須藤勝一・志野晟生・藤田 剛*
}

Acceleration of wound healing by recombinant human basic fibroblast growth factor in a rat sponge-implantation model

The effect of recombinant human basic fibroblast growth factor (rhbFGF) on wound healing was studied biochemically and histologically in a rat spongeimplantation model. Administration of 2 or $10 \mu \mathrm{g} /$ rat of $\mathrm{rhbFF}$ to a sponge piece increased the protein and DNA contents of the sponge as well as the wet weight, 1 and 2 weeks after the implantation. One week after the implantation of the rhbFGF-pellet, increases in capillary formation and infiltration of cellular and fibrillar components were histologically observed. The hemogiobin content of the sponge piece also significantly increased, suggesting that the hemoglobin content is a good biochemical marker for angiogenesis and wound healing process. The collagen content of rhbFGF-containing pellet was not significantly different from that of the control.

The effect of rhbFGF on the hemoglobin content was totally abolished by rhbFGF-neutralizing antibody. The results indicate that rhbFGF exhibits its angiogenic action in vivo and suggest that it accelerates wound healing.

Masuo Yamaoka • Tsuneo Masaki - Katsuichi Sudo • Akio Shino - Takeshi Fujita*

key words : wound healing, rat spongeimplantation, recombinant human basic fibroblast growth factor

創傷治癒には, 血管新生, 肉芽組織の発達, コ ラーゲンの産生，上皮の形成などの過程が含まれ $る^{1}$. 一一方, 塩基性線維芽細胞成長因子(basic fibroblast growth factor, bFGF)は, 創傷治癒に掠 いて重要な血管内皮細胞や血管平滑筋細胞, 線維 芽細胞などの細胞増殖を促進し，血管新生を促進 する2,3). したがって, bFGF は，これらの過程を 促進することにより，創傷治癒を早める可能性が 考学られる。大腸菌で発現された組換兄型ヒト $\mathrm{bFGF}(\mathrm{rhbFGF}$ )の精製標品は抽出ウシ由来 bFGF と同じように血管新生活性を示すことが明らかに されている4).

* Biology Research Laboratories, Research and Development Division, Takeda Chemical Industries, Ltd. 武田薬品研究開発本部生物研究所
本研究は，精製された rhbFGF を使用して， ラットスポンジ移植による創傷モデルに拉ける作 用を検討するために行った。

\section{材料と方法}

(1) 材 料

rhbFGF は大晹菌で発現し, heparin-affinity カ ラムを使用して電気泳動的に単一の成分にまで精 製された標品を当社生物工学研究所五十嵐貢一博 士から供与された。 bFGF の活性を中和するモノ クローナル抗体は, 当社生物研究所香西義雄博士 から供与された。 その標品中のエンドトキシン 含量は, リムルステストで測定すると重量比で rhbFGF の約 20 万分の 1 程度であり, 実験に影響 しないと判定した。プロテインアッセイキットは Bio-Rad 社より，へモグロビン測定キット括よび 一般試薬は和光純薬より，それぞれ購入した。埋 め込み用スポンジは，ポリウレタン製のものを10 $\mathrm{mM}$ EDTA を含む $10 \mathrm{mM}$ リン酸 ナトリウム緩 衝液( $\mathrm{pH}$ 7.4), 扎よび超純水(Barnstead NANOpure II)で洗浄後，オートクレーブで隇菌し乾燥 させてから使用した。

(2) スポンジ移植法

rhbFGF を含む徐放性ペレットは， Murray ら の方法 ${ }^{5)}$ にほぼ従って以下のように調製した。 8 $\%$ ethylene-vinylacetate copolymer(EVA)の $\mathrm{CH}_{2}$ $\mathrm{Cl}_{2}$ 溶液 $10 \mu \mathrm{l}$ を乾固し，そのうえで $\mathrm{rhbFGFの}$ 溶液（2 あるいは $10 \mu \mathrm{g} / 5 \mu l ， 0.1 \%$ 卵白アルブ ミン, $8 \mathrm{mM}$ リン酸ナトリウム, $\mathrm{pH} 7.4,80 \mathrm{mM}$ $\mathrm{NaCl}$ )を乾固した。ささらに，そのうえに $10 \mu l$ の EVA 溶液を乾固した後ピンセットで折りたたみ, ペレットを作成した。このペレットをスポンジ $(10 \mathrm{~mm} \times 10 \mathrm{~mm} \times 6 \mathrm{~mm})$ の中央部飞插入し，そ のスポンジをラット $(11 \sim 13$ 週齢 SD 系雄性, 日 本チャールズリバー)の後背部皮下に移植した.

対照群ラットには， xhbFGF のかわりに同量の BSA を含む $\mathrm{EVA}$ ペレットを作成してスポンジ 


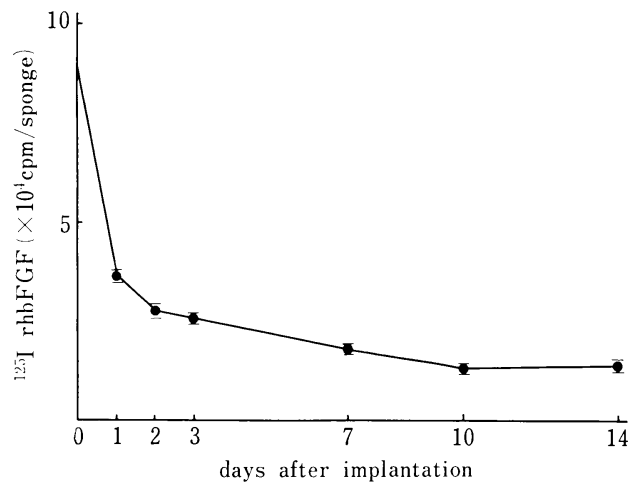

図1 スポンジからの rhbFGF の消失のタイムコ ース

約 $1 \times 10^{5} \mathrm{cpm}(10 \mu \mathrm{g})$ の $^{125} \mathrm{I}-\mathrm{rhbFGF}$ を含む ethylene-vinylacetate copolymer のペレットを挿入した スポンジをラット皮下に移植し，一定期間後に取り 出してスポンジ中に残存する放射活性を測定した。 $($ mean \pm SEM $)(n=3)$

に挿入し皮下に移植した. $1 \sim 3$ 週後エーテル麻 酔下にスポンジを摘出した。科量後，スポンジを 2 等分し，一方を生化学的分析に使用し，他方を 形態学的検索に使用した。

（3）スポンジの生化学的分析および形態学的検 索

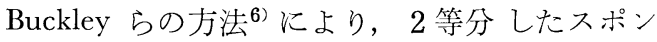
ジを $0.1 \mathrm{M} \mathrm{NH} \mathrm{NH}_{4} \mathrm{OH} 1$ 昼夜浸して蛋白質括よ び DNAを抽出した，蛋白質はプロテインアッセ イキット，DNA は螢光色素をを使用してそれぞ れ定量した。へモグロビンは測定キットで定量し た.コラーゲン含量は，残椬を $6 \mathrm{~N} \mathrm{HCl}$ 中, 110 ${ }^{\circ} \mathrm{C}$ で 1 晚加水分解し，ヒドロキシプロリンを定 量することにより求めた ${ }^{8)}$.

残りのスポンジは，10\%中性緩衝ホルマリン液 で固定後，パラフィン包埋薄切切片を作成し， へ マトキシリンーエオジン染色拈よびアザン染色を 行い検鏡した。一部のスポンジは細切し， $0.1 \mathrm{M}$ リン酸緩衝 $2.5 \%$ グルタルアルデヒド固定液 $(\mathrm{pH}$ 7.4，4 ${ }^{\circ} \mathrm{C)}$ ) で固定した. 同じ緩衝液で洗ったあと, $1 \%$ オスミウム酸液で再固定し, エタノールで脱 水後, Epok 812 に包埋した。超薄切片を作成し, 酢酸ウランとクエン酸鉛で染色後電子顕微鏡観察 した。

（4）中和モノクローナル抗体による $\mathrm{rbbFGF} の$ 血管新生促進効果の阻害

rhbFGF の中和モノクローナル抗体およびマウ
ス IgG (Jackson Immunoresearch)を $5 \mathrm{mM}$ リン 酸緩衝液 $(\mathrm{pH}$ 7.4) に対して透析後，セントコリ ン10(アミコン)で濃縮した。このモノクローナル 抗体あるいはマウス IgG と $\mathrm{rhbFGF}$ を重量比で 100：1 となるように混合し， $4^{\circ} \mathrm{C}$ で一晚プレイ ンキューベーションした。

ペレット当り $2 \mu \mathrm{g}$ の $\mathrm{rhbFGF}$ および $200 \mu \mathrm{g}$ のモノクローナル抗体あるいはマウス IgG を含 さように徐放性ペレットを作成し，ラットの背部 に移植した． 1 週後にスポンジを摘出し，へモグ ロビン含量を測定した。

(5) $\mathrm{rhbFGF}$ の標識法と徐放性ペレットからの 放出

クロラミン $\mathrm{T}$ 法9”により ${ }^{9 h b F G F}{ }^{125} \mathrm{I}-\mathrm{NaI}$ (New England Nuclear Corp.)でョードラベル化 したあと, heparin-Sepharose (Pharmacia)カラム を使用して分離精製した。 $10 \mu \mathrm{g}$ の $\mathrm{rbFGF}$ と約 $1 \times 10^{5} \mathrm{cpm}$ の ${ }^{125} \mathrm{I}-\mathrm{rhbFGF}$ を含む $\mathrm{EVA}$ ペレッ トを作成し，スポンジ移植法と同様にスポンジと ともにラット皮下に移植した，経日的にラットか らスポンジを取り出し, ガンマカウンター(Aloka ARC-600)中で放射活性を測定した。

移植 1 日後には，スポンジ中に残存する放射活 性は, 移植前の約 $40 \%$ をで急激に減少し, その後 は徐々に減少して, 7 日後では約 $20 \%$ が残存した (戍 1 ).

\section{成 績}

(1) 生化学的分析

rhbFGF 投与 1 週後のラットから摘出したスポ ンジは, 対照と比較して, 大きく, 堅く, 切断面 はいちじるしく赤色味を帯びていた。 2 週以降は 対照スポンジの赤色味も顕著となり，投与群との 間に色調の差は認められなかった。

スポンジ湿重量は，10 $\mu \mathrm{g} / \mathrm{rat}$ の $\mathrm{rhbFGF}$ 投与 群に拈いて 1 および 2 週後, 対照と比較して有意 に増加した(困 $2 \mathrm{a})$ ）。た， スポンジの蛋白質お よび DNA 含量も 2 および $10 \mu \mathrm{g} / \mathrm{rat}$ の rhbFGF 投与群に拈いて，1週後には対照と比較して有意 に增加した(図 $2 \mathrm{~b} ・ \mathrm{c}$ ).

スポンジのへモグロビン含量は，2または 10 $\mu \mathrm{g} / \mathrm{rat}$ の $\mathrm{rbbFF}$ 投与群において，1週後には 用量依存的に顕著に増加した。 しかし， 2 週後で は，対照と投与群との間に差は認められなかった 

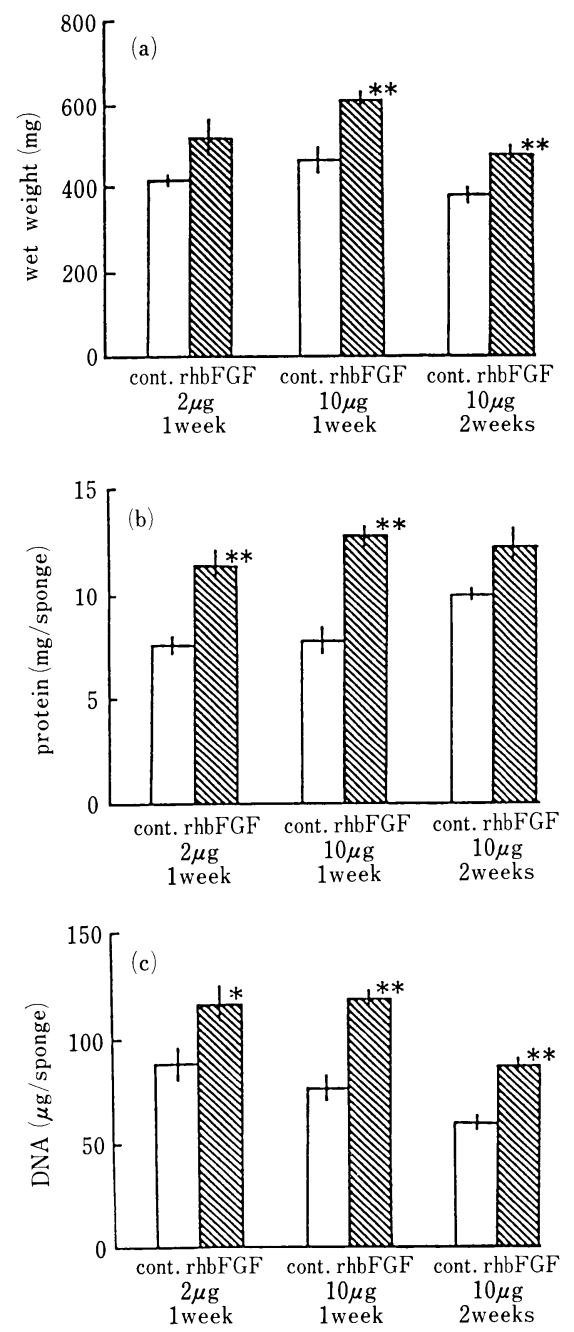

図 2 rhbFCF によるスポンジの湿重量, 蛋白質含 量扰よび DNA 含量の変化

rhbFGFを含むスポンジをラットに移植し，一定期 間後に取り出してスポンジ中の各成分を測定した。 $\mathrm{a}$ : 湿重量 $(\mathrm{mg}), \mathrm{b}$ : 蛋白質含量 (mg/sponge). c : DNA 含量 $(\mu \mathrm{g} /$ sponge $)($ mean \pm SEM $)(n=6)$. $*: \mathrm{P}<0.05$. ** : $\mathrm{P}<0.01$ (t-test)

(図 $3 \mathrm{a}$ ).

コラーゲン含量は，対照および投与群のいずれ も時間経過とともに増加した(図 $3 \mathrm{~b}$ ). しかしな がら，3 週まで rhbFGF 投与による促進がみら れず，生しろ対照と比較してやや低值を示した。

rhbFGF のこれらの作用がその試料中に混在す る物質による可能性を除くために，in vitro で中 和活性を持つモノクローナル抗体が，rhbFGF に よるへモグロビン含量の増加作用に及ぼす影響を 調べた(図 4).
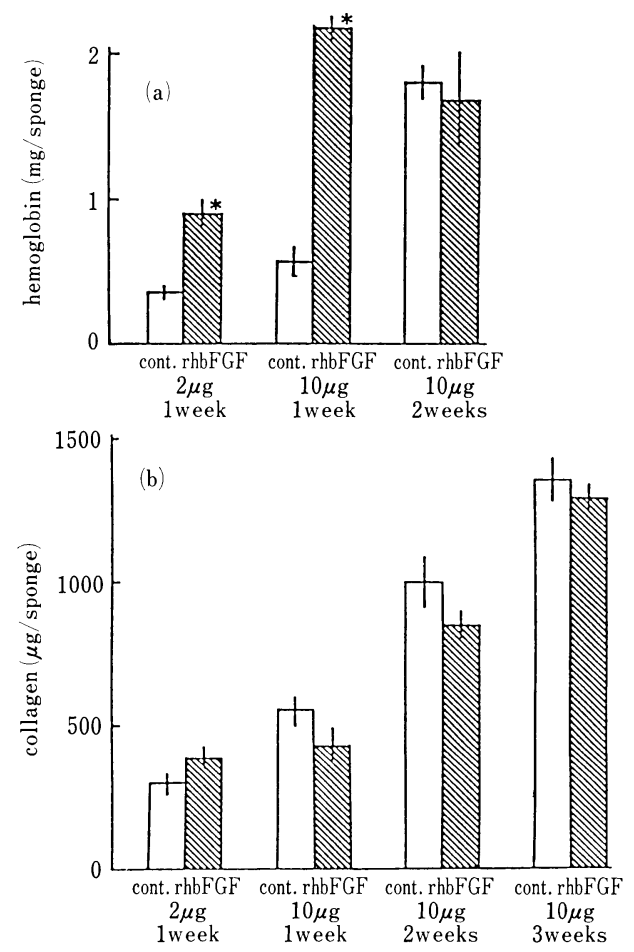

図 3 rhbFGF によるスポンジ中へモグロビン含量 打よびュラーゲン含量の変化

rhbFGF を含むスポンジをラットに移植し，一定期 間後に取り出してスポンジ中の各成分を測定した。 $\mathrm{a}$ ：へモグロビン含量( $\mathrm{mg} /$ sponge). b : コラーゲン 含量 $(\mu \mathrm{g} /$ sponge $)($ mean $\pm \mathrm{SEM})(\mathrm{n}=6)$.

* $: \mathrm{P}<0.05$. ** $: \mathrm{P}<0.01$ (t-test)

rhbFGF およびマウス IgG を含もスポンジで は，対照群のスポンジにくらべて有意にへモグロ ビン含量が増加していた，一方，マウス IgG の みを含をスポンジのへモグロビン含量は対照群と 差がなかった。このマウス IgGを同量の rhbFGF の中和モノクローナル抗体と置き換えると，スポ ンジ内のへモグロビン含量は対照群のレベルまで 低下した。

(2) 組織学的分析

スポンジを 2 等分し，その一方をへマトキシリ ンーエオジン染色およびアザン染色し, 細胞成分 ならびにコラーゲン線維について形態学的に調べ た. スポンジの形態学的特徵を, 外, 中間, およ び内の 3 層にわけ，対照と投与群とで比較した。

(1) 投与 1 週後( $\mathrm{rhbFGF} \mathrm{:} 10 \mu \mathrm{g} / \mathrm{rat}$ )

対照群：スポンジ断面は投与群と比較して赤色 味が少なく，スポンジの周囲の肉芽組織量が少な 
表 $1 \mathrm{rhbFGF}$ の肉芽形成に及ぼす影響 $(10 \mu \mathrm{g}, 1$ 週)

\begin{tabular}{|c|c|c|c|c|c|c|c|c|c|c|c|c|}
\hline \multirow{2}{*}{ rat No. } & \multicolumn{6}{|c|}{ control } & \multicolumn{6}{|c|}{ rhbFGF } \\
\hline & 1 & 2 & 3 & 4 & 5 & 6 & 1 & 2 & 3 & 4 & 5 & 6 \\
\hline \multicolumn{13}{|l|}{ outer zone of the sponge } \\
\hline fibroblast & + & + & + & + & + & + & H & $H$ & + & + & H & H \\
\hline collagen fiber & + & + & + & + & + & + & $H$ & + & H & + & + & + \\
\hline capillary & \pm & + & + & + & + & + & H & + & + & + & + & + \\
\hline inflammatory cells & \pm & \pm & \pm & \pm & \pm & \pm & + & + & \pm & \pm & + & \pm \\
\hline middle zone of the sponge & & & & & & & & & & & & \\
\hline fibroblast & \pm & \pm & \pm & \pm & \pm & \pm & + & + & \pm & \pm & \pm & + \\
\hline capillary & - & - & - & - & - & - & + & \pm & \pm & - & - & \pm \\
\hline red blood cells & - & \pm & \pm & - & - & - & + & + & + & + & + & H \\
\hline inflammatory cells & \pm & \pm & \pm & \pm & \pm & \pm & + & + & + & + & H & H \\
\hline fibrin network & + & $\dashv$ & + & + & + & + & + & + & + & + & + & + \\
\hline inner zone of the sponge & & & & & & & & & & & & \\
\hline red blood cells & - & \pm & \pm & - & - & - & + & \pm & + & \pm & \pm & + \\
\hline inflammatory cells & \pm & \pm & \pm & \pm & \pm & \pm & + & \pm & + & \pm & \pm & + \\
\hline fibrin network & + & + & + & + & + & + & H & + & + & + & + & + \\
\hline capillary & - & - & - & - & - & - & - & - & - & - & - & - \\
\hline
\end{tabular}

- : no. \pm : slight. + : mild. + : moderate

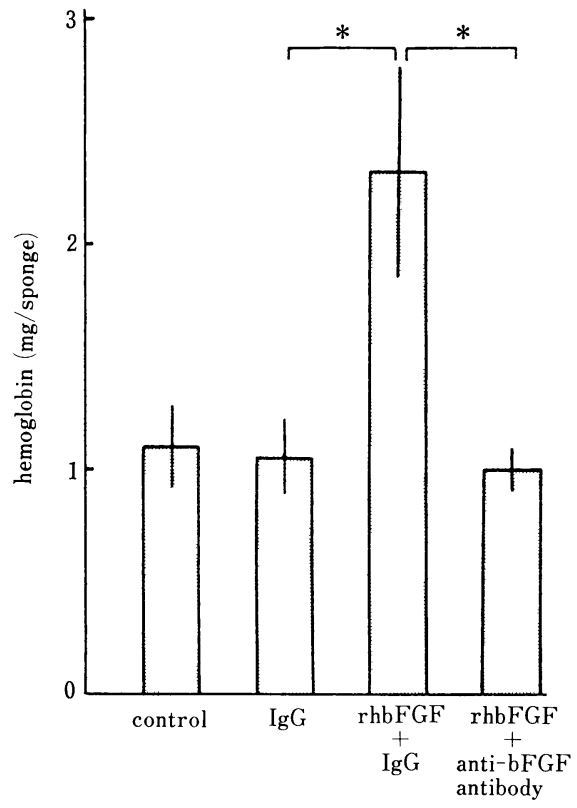

図 4 中和モノクローナル抗体による rhbFGF のへ モグロビン含量の増加作用の抑制

$2 \mu \mathrm{g}$ の $\mathrm{rhbFGF}, 2 \mu \mathrm{g}$ の $\mathrm{rhbFGF}$ と $200 \mu \mathrm{g}$ のマ ウス $\mathrm{IgG}, 2 \mu \mathrm{g}$ の $\mathrm{rhbFGF}$ そ $200 \mu \mathrm{g}$ の $\mathrm{rhbFGF}$ の中和抗体を含むスポンジをラットに移植し，1週 後に摘出してスポンジ内のへモグロビン含量を測定 した。

$($ mean $\pm S E M)(n=4) . *: P<0.05$ (t-test)
いことが実体顕微鏡により観察された(図 $5 \mathrm{a}$ ). スポンジ外層には軽度の線維性結合組織層の形成 がみられ，線維芽細胞，毛細血管和よび少量の炎 症性細胞浸潤(好中球，マクロファージ，好酸球) がみられた(図 $5 \mathrm{~b} ・ \mathrm{~d}$ ). アザン染色によりコラー ゲン線維束が認められた(図 $5 \mathrm{c}$ )。 中間層にはフ ィブリンがスポンジの網目内に析出していたが, 細胞浸潤はわずかに認められるのみであった(図 $5 \mathrm{~b})$. スポンジの内層にはフィブリンの析出はわ ずかで, 赤血球および炎症性細胞浸潤はほとんど 認められなかった(データ省略).

投与群：スポンジ断面は対照群と比較して赤色 味が顕著で，スポンジ周囲の肉芽組織量は豊富に 認めら机た(図 $5 \mathrm{e}$ )。スポンジ外層には線維芽細 胞が対照に比較して密に収束する部位が散見され た(図 $5 \mathrm{f})$ ） その部位のコラーゲン線維は比較的 粗鬆であった(図 $5 \mathrm{~g}$ )。しかし，コラーゲン線維 は外層から中間層にかけて対照と比較して内部に まで観察された。好中球，マクロファージ，好酸 球などが少数みられた。外層から中間層にかけて 線維芽細胞が比較的多数みられ，毛細血管も認め られた(図 $5 \mathrm{f} ・ \mathrm{~h}$ ). 内層に打いては, 対照と比較 してフィブリンの析出とともに赤血球拈よび好中 球がやや多く認められた(図省略)，表 1 亿成績の 
a

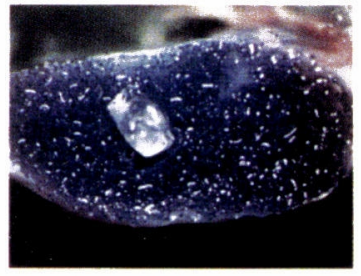

b

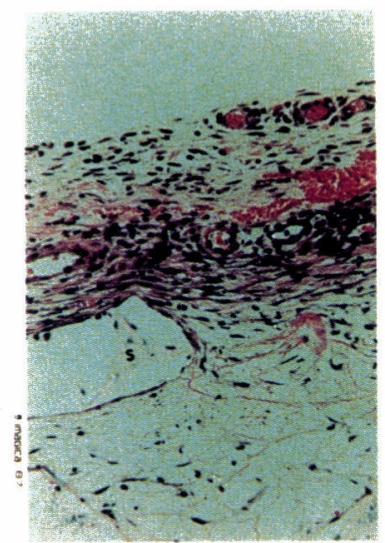

C
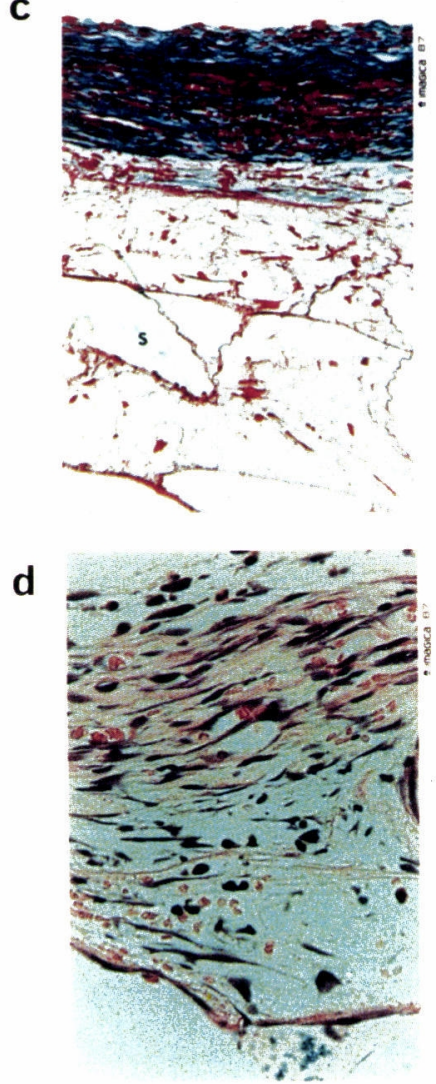

e

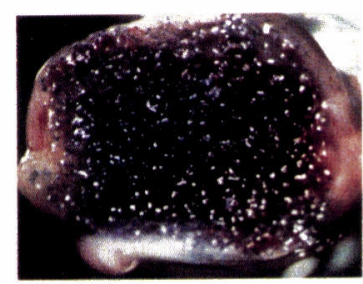

f

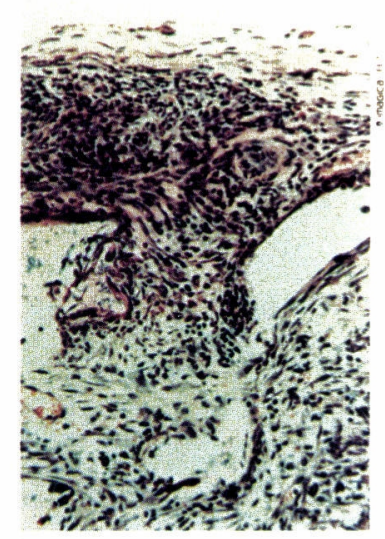

g

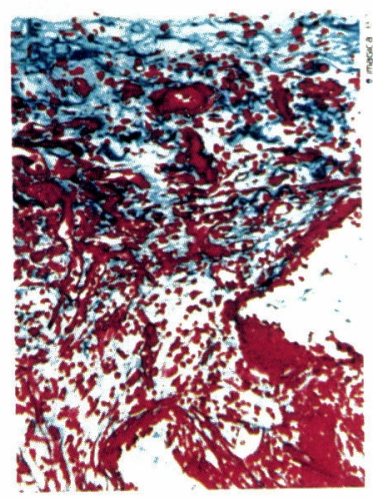

$\mathbf{h}$

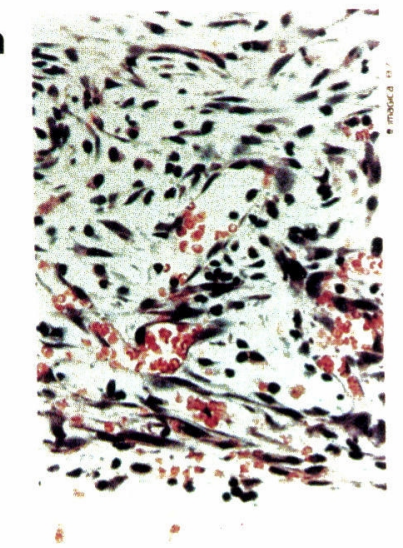

$\mathrm{a} ・ \mathrm{e} ：$ スポジ断面の実体顕微鏡 写真

$\mathrm{b} \cdot \mathrm{f}:$ スポンジ外層から中間層に かけての HE 染色 $(\times 260)$

$\mathrm{c} \cdot \mathrm{g}:$ スポンジ外層から中間層に かけての Azan 染色 $(\times 260)$ $\mathrm{d} \cdot \mathrm{h}:$ スポンジ中間層の HE 染 色 $(\times 520)$

a d : 対照

$\mathrm{e} \sim \mathrm{h}$ : 投与群

图 $5 \mathrm{rhbFGF}$ 投与スポンシの形態学的観察

$10 \mu \mathrm{g}$ の rhbFF とともに移植したスポンジを 1 週後に取り出し, へマトキ シリンーエオジン打よびアザン染色により形態学的に観察した。 
表 $2 \mathrm{rhbFGF}$ の肉芽形成に及ぼす影響 $(10 \mu \mathrm{g}, 2$ 週)

\begin{tabular}{|c|c|c|c|c|c|c|c|c|c|c|c|c|}
\hline \multirow{2}{*}{ rat No. } & \multicolumn{6}{|c|}{ control } & \multicolumn{6}{|c|}{ rhbFGF } \\
\hline & 1 & 2 & 3 & 4 & 5 & 6 & 1 & 2 & 3 & 4 & 5 & 6 \\
\hline \multicolumn{13}{|l|}{ outer zone of the sponge } \\
\hline fibroblast & + & + & + & + & + & + & + & + & + & + & + & + \\
\hline collagen fiber & H & H & H & H & H & $H$ & + & H & H & $H$ & H & H \\
\hline capillary & + & H & + & + & + & + & + & + & + & + & + & + \\
\hline inflammatory cells & \pm & \pm & \pm & + & \pm & \pm & \pm & \pm & + & + & + & \pm \\
\hline giant cells & H & $H$ & H & $H$ & H & H & H & $H$ & H & H & H & H \\
\hline middle zone of the sponge & & & & & & & & & & & & \\
\hline fibroblast & H & H & H & H & H & H & + & + & + & + & + & + \\
\hline collagen fiber & $H$ & H & $H$ & H & Ht & H & + & + & H & + & + & + \\
\hline capillary & + & $H$ & $H$ & H & Ht & + & H & $H$ & H & H & H & + \\
\hline red blood cells & + & H & H & + & + & + & + & + & + & + & + & + \\
\hline inflammatory cells & \pm & \pm & \pm & \pm & \pm & \pm & \pm & \pm & + & \pm & + & \pm \\
\hline fibrin network & + & - & - & \pm & - & + & - & - & - & - & - & - \\
\hline \multicolumn{13}{|l|}{ inner zone of the sponge } \\
\hline red blood cells & + & H & + & + & + & + & \pm & + & H & \pm & + & \pm \\
\hline inflammatory cells & \pm & \pm & \pm & \pm & \pm & \pm & \pm & \pm & \pm & \pm & \pm & 土 \\
\hline fibrin network & + & H & + & + & + & + & + & + & H & H & + & + \\
\hline capillary & - & - & - & - & - & - & - & - & - & - & - & - \\
\hline
\end{tabular}

- : no. \pm : slight. + : mild. $\#$ : moderate

表 3 rhbFGF の肉芽形成に及洔す影響 (10 $\mathrm{g}, 3$ 週)

\begin{tabular}{|c|c|c|c|c|c|c|}
\hline \multirow{2}{*}{ rat No. } & \multicolumn{3}{|c|}{ control } & \multicolumn{3}{|c|}{ rhbFGF } \\
\hline & 1 & 2 & 3 & 1 & 2 & 3 \\
\hline \multicolumn{7}{|l|}{ outer zone of the sponge } \\
\hline fibroblast & + & + & + & + & + & + \\
\hline collagen fiber & H & H & H & H & H & 卅 \\
\hline capillary & + & + & + & + & + & + \\
\hline inflammatory cells & + & + & + & H & + & + \\
\hline giant cells & H & H & $H$ & H & $H$ & H \\
\hline \multicolumn{7}{|l|}{ middle zone of the sponge } \\
\hline fibroblast & H & H & H & H & H & H \\
\hline collagen fiber & H & H & H & + & + & H \\
\hline dilatation of capillary & $H$ & + & + & H & $H$ & H \\
\hline inflammatory cells & + & + & + & + & $H$ & + \\
\hline giant cells & H & H & H & H & $H$ & H \\
\hline edema & + & + & + & H & H & H \\
\hline \multicolumn{7}{|l|}{ inner zone of the sponge } \\
\hline collagen fiber & + & + & + & \pm & \pm & + \\
\hline dilatation of capillary & H & + & H & H & HH & H \\
\hline inflammatory cells & + & + & + & + & + & + \\
\hline giant cells & + & H & H & + & + & + \\
\hline edema & + & + & $H$ & H & H & H \\
\hline
\end{tabular}

- : no. \pm : slight. + : mild. $\#$ : moderate. H: severe
まとめを示す。

$2 \mu \mathrm{g} / \mathrm{rat}$ の $\mathrm{rbbFF}$ 投与 1 週後においても, ほぼ同様の傾向がみられたが，コラーゲン線維は 対照群と同程度であった。 また，中間層および 内層に和ける細胞浸潤も軽度であった(データ省 略).

(2) 投与 2 週後(rhbFGF : $10 \mu \mathrm{g} / \mathrm{rat}$ )

対照群：外層に線維性結合組織層が形成される とともに，中間層にもよく発達したコラーゲン線 維層の形成が認められた(表 2). スポンジに接し て多核巨細胞が認められた。 また，中間層から内 層に向けて紡錘形の細胞が多数伸長していた。こ の部でしばしば微小出血が認められた。

投与群：外層にコラーゲン線維が豊富に分布し ていたが，対照よりやや粗であり，細胞密度も対 照よりやや粗であった，巨細胞は対照と同程度で あった。中間層もコラーゲン線維が豊富に分布し ていたが対照よりやや粗であり，細胞密度も対照 よりやや粗であった。 巨細胞は対照と同程度であ った．毛細血管は多数認められた．内層の細胞密 度は対照と比較してやや粗であった，巨細胞は対 照と同程度であった。毛細血管が多数認められ た，表 2 にまとめを示す。 
電子顕微鏡による観察で毛細血管の管腔が認め られ，周細胞の毛細血管への付着がみられた(デ 一夕省略).

(3) 投与 3 週後 (rhbFGF : $10 \mu \mathrm{g} / \mathrm{rat}$ )

全体としては 2 週後と同傾向にあったが，スポ ンジ内部の浮腫が投与群でめだった(表 3 ).

\section{考 察}

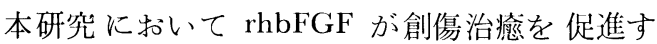
ることを示唆する成績を得た，rhbFGF を徐放性 ペレットとしてスポンジ中に挿入し，ラットに皮 下移植した結果，スポンジ中の蛋白質，DNAな ど肉芽組織の成分が対照と比較して有意に上昇し た。移植 1 週後，スポンジ中のへモグロビン含量 は，特に対照と比較して顕著に上昇した。光顕に よる観察に打いても rhbFGF 移植 1 週後のスポ ンジ中には毛細血管が収束している像が認められ たことから，へモグロビン含量は，bFGF などの 成長因子による血管新生および創傷治癒過程のよ いマーカーと考えられる。移植 2 週後には対照と 投与群との間でへモグロビン含量に差はなくな り， $\mathrm{rhbFGF}$ の作用は血管新生を早めることにあ ることがわかった. コラーゲン含量は rhbFGF 投 与 3 週後まで対照と比較して差は認められなかっ た。対照群のスポンジ中コラーゲン含量が週とと もにしだいに上昇しており，コラーゲン合成は対 照スポンジ移植によりすでに刺激されていること がわかる、したがって， rhbFGFをさらに加え ても，それ以上の促進は認められなかった可能性 がある。あるいは rhbFGF にはコラーゲン合成 を刺激する作用はないとも考学られる。

一方，スポンジを 3 層に分類して形態学的に検 索した結果，コラーゲンのスポンジ中間層への移 行は rhbFGF 投与群のスポンジに执いてょり, 一層明白に認められた。 しかし，コラーゲン含量 の大部分はスポンジを取り巻く肉芽組織に存在す るため, rhbFGF によるスポンジ内部のコラーゲ ン上昇は，スポンジ全体を用いて測定したスポン ジ含量に反映されなかったと思われる。スポンジ 移植法そのものは肉芽組織の形成を調べるモデル であるが，移植直後は空隙がスポンジ内部の大部 分を占めることから, 欠損傷のモデルでもあると 考えられる。したがって，欠損傷や裂傷などの創 傷に対して rhbFGF を投与した場合には, 上記
スポンジ中間層におけるコラーゲン含量の増加の 成績に対応して，コラーゲン含量増加を伴ら治瘉 促進が認められると予想される。 rhbFGF のコラ ーゲン含量に及ぼす影響に結論を下すには，異物 を移植する本モデル以外に久損傷などの治癒過程 に拉けるコラーゲン含量の変動を調べることが必 要であろら.

以上のように，高度に精製 した rhbFGF 投与. により創傷治癒のマーカーが動くことが示され た。しかし，この作用が rhbFGF の試料中に混 在する微量成分に対する非特異的な炎症反応によ る可能性が残るので, in vitro で rhbFGF の活性 を中和するモノクローナル抗体(Hori ら，投稿準 備中)が rhbFGF の創傷治癒促進作用に及ぼす影 響を調べた。その結果, rhbFGF のスポンジ内の へモグロビン含量増加作用が，この抗体で対照群 のレベルまで抑制されたので，これらの作用が非 特異的な炎症反応による可能性は少ないと考光ら れる。

本研究の成績を1988年 7 月の日本炎症学会にて 報告後, 組換光型 bFGF のラット皮膚裂傷 モデ ルに抢ける作用についての成績が発表された ${ }^{10)}$. その報告では, rbFGF により引っ張り力や breaking energy はいずれも増加したが, コラーゲン 含量は有意な増加を示して抢らず，本研究の成績 と矛盾しない内容であった。ウシ軟骨由来の成長 因子を抽出精製してスポンジ移植モデルに扣いて 治瘾促進を調べた成績が報告されている ${ }^{11)}$ 。この 因子は，のちに bFGF と同一であることが明ら かになったが，スポンジモデルに拉いてこの因子 はコラーゲン含量を増加させたと報告されてい る。これは組換え型 bFGF を使用した，筆者ら および上記の皮覤裂傷モデルに拈ける成績とは異 なる。

現時点に和いてこの差がなにに由来するか明ら かではないが，動物組織から調製した因子の場 合，抽出，精製標品中に混在する他の成長因子 が，成績に影響する可能性も無視できないである ら.

\section{文 献}

1) Clark, R.A.F.: Overview and general considerations of wound repair. The Molecular and Cellular Biology of Wound Repair. (ed. Clark, R.A.F., Henson, P.M.), Plenum Press, New 
York, 1988, p 3-33.

2) Baird, A., Esch, F., Mormede, P., Ueno, N., Ling, N., Boehlen, P., Ying, S.Y., Wehrenberg, W.B., Guillemin, R.: Molecular characterization of FGF: distribution and biological activities in various tissues. Recent Frogress in Hormone Research 42: 143-205, 1986.

3) Gospodarowicz, D., Ferrara, N., Schweigerer, L., Neufeld, G.: Structural charcterization and biological functions of fibroblast growth factor. Endocrine Reviews 8: 95-114, 1987.

4) Seno, M., Sasada, R., Iwane, M., Sudo, K., Kurokawa, T., Ito, K., Igarashi, K.: Stabilizing basic fibroblast growth factor using protein engineering. Biochem. Biophys. Res. Commun. 151: 701-708, 1988.

5) Murray, J.B., Brown, L., Langer, R., Klagsbrun, M.: A micro sustained release system for epidermal growth factor. In Vitro. 19: 743-748, 1983.

6) Buckley, A., Davidson, J.M., Kamerath, C.D., Wolt, T.W., Woodward, S.C.: Sustained release of epidermal growth factor accelerates wound repair. Proc. Natl. Acad. Sci. USA 82: 7340-
7344, 1985.

7) Labarca, C., Paigen, K.: A simple, rapid, and sensitive DNA assay procedure. Anal. Biochem. 102: 344-352, 1980.

8) Blumenkrantz, N., Asboe-Hansen, G.: An assay for hydroxyproline and proline on one sample and a simplified method for hydroxyproline. Anal. Bioehem. 63: 331-340, 1975.

9) Hunter, W.M., Greenwood, F.C.: Preparation of iodine-131 labeled human growth hormone of high specific activity. Nature 194: 495-496, 1962.

10) McGee, G.S., Davidson, J.M., Buckley, A., Sommer, A., Woodward, S.C., Aquino, A.M., Barbour, R., Demetriou, A.A.: Recombinant basic fibroblast growth factor accelerates wound healing. J. Surgical Res. 45: 145-153, 1988.

11) Davidson, J.M., Klagsbrun, M., Hill, K.E., Buckley, A., Sullivan, R., Brewer, P.S., Woodward, S.C.: Accelerated wound repair, cell proliferation and collagen accumulation are produced by a cartilage-derived growth factor. J. Cell Biol. 100: 1219-1227, 1985. 